\title{
The magnetic method as a tool in groundwater investigation in a basement complex terrain: Modomo Southwest Nigeria as a case study
}

\author{
Ademakinwa George Oni ${ }^{1}$ D . Ponmile Japheth Eniola ${ }^{1} \cdot$ Martins Olusola Olorunfemi $^{1} \cdot$ Michael Olajide Okunubi $^{2}$. \\ Gaius Abayomi Osotuyi ${ }^{1}$
}

Received: 28 November 2019 / Accepted: 6 July 2020 / Published online: 13 July 2020

(c) The Author(s) 2020

\begin{abstract}
A detailed ground magnetic survey was carried out in a basement complex underlain Modomo community in southwestern Nigeria with a view to delineating the subsurface structures, estimate the overburden thicknesses and assess the relevance of the geophysical method in groundwater investigation in the locality. The total field component of the earth's magnetic field was measured at station intervals of 10-100 $\mathrm{m}$ along access routes within the study area. The data were corrected for diurnal variation and offset and subsequently reduced to the magnetic equator (RTE). Data enhancement techniques including the second vertical derivative, total horizontal derivative and Euler deconvolution were applied to the RTE data to map edges and estimate depths to the structures. Overburden thicknesses were estimated from 2D magnetic subsurface modeling along eight profiles. The magnetic survey derived lineaments (structures) and overburden thicknesses were validated with resistivity survey derived 2D structures and overburden thicknesses and borehole log data from the study area. Twenty-four lineaments with lengths ranging from 150 to $777 \mathrm{~m}$ were identified from the magnetic map. The lineament orientations were E-W, ENE-WSW, WNW-ESE, NNW-SSE, NW-SE and NE-SW directions. Many of the identified lineaments correlated significantly with structures derived from the 2D resistivity images. Comparable thicknesses were observed between correlated magnetic derived overburden thicknesses (4.41-29.4 m) and depths from wells and boreholes (5.48-27.1 m). The study concluded that the magnetic method could be reliably used for overburden thickness estimation and structure mapping required in groundwater potential assessment in a typical basement complex terrain.
\end{abstract}

Keywords Basement complex terrain $\cdot$ Geologic structures $\cdot$ Groundwater investigation $\cdot$ Magnetic method

\section{Introduction}

Hydro-geophysical investigation, most especially in groundwater development-related problems, often involves assessment of aquifer potential, water quality and pollution assessment and aquifer vulnerability/protective capacity study among others (Kinnear et al. 2013; Orakwe et al. 2018; Olorunfemi and Oni 2019). Regardless of the focus of such

Ademakinwa George Oni

oniademakinwa@yahoo.com

1 Department of Geology, Obafemi Awolowo University, Ile-Ife, Osun State, Nigeria

2 Department of Geoscience, Mountain Top University, Prayer City, Ibafo, Ogun State, Nigeria study, the major targets are the aquifer unit(s) and the overlying materials.

In a typical basement terrain, groundwater is located in weathered and fractured aquifers (Olorunfemi and Fasuyi 1993; Macdonald and Calowb 2008; Olorunfemi and Oni 2019) and in the transition zone (partly weathered basement) between the weathered rock and the fresh bedrock (Acworth 2001). Unlike in the sedimentary environment, aquifer lateral and depth extents vary considerably (Acworth 2001; Kumar et al. 2007). While some areas are associated with relatively high overburden thicknesses and high fracture densities with consequently high groundwater potential, other areas could be devoid of subsurface structures (fault, fracture and shear zones) with basement outcropping in most places with tendency for very low groundwater potential (Chirindja et al. 2017). 
Information on aquifer thickness and properties (porosity, permeability) and their spatial variability among other hydrogeological factors required for proper assessment of groundwater potential, siting of productive borehole, formulation of best exploitation and development technique(s) and the cost estimation are derivable from the results of geophysical investigation (MacDonald and Calowb 2008). The geophysical methods that are applicable in hydrogeological studies include the electromagnetic, resistivity, magnetic and the seismic methods. The electrical resistivity and electromagnetic methods have proven to be the most useful methods because the hydrogeological parameters such as aquifer porosity and permeability and the concentration of the saturating fluid significantly determine the electrical resistivity/ conductivity that is measured (Zohdy 1969; Ogilvy 1970; Paillet 2013). These methods also enable large-scale aquifer characterization that may not be possible through conventional (borehole drilling, pump testing and core sampling) techniques in a minimally/or noninvasive and cost-effective manner (Robinson et al. 2013; Ruggeri et al. 2013; Deng et al. 2016).

The magnetic method is probably the most versatile of all the geophysical methods (Dobrin and Savit 1988) because it can be applied to both shallow and deep seated targets. It is also relatively cheap for both local and regional studies. Since the early 1900s, the magnetic method has been used primarily for regional survey in hydrocarbon and mineral explorations. Such applications include mapping of geological structures and igneous intrusions and in the estimation of sedimentary basin thickness. Much of the shallow subsurface investigations are directed toward characterizing the sediments above the bedrock, defining the bedrock topography and delineating buried metallic objects (Babu et al. 1991; Urban et al. 2012). The main application of the magnetic method in groundwater investigation had been in defining large-scale basin structures and regional aquifers. Babu et al. (1991); Olorunfemi et al. (1986) and Olorunfemi and Oni (2019) used the method to map bedrock topography, basement faults/fractures and the location of crustal weakness that may represent preferential fluid flow paths. Its application in mapping unconsolidated sequence is limited as magnetic signatures for different sediment horizons are often weak. The method is therefore not directly and commonly used for detailed groundwater and shallow subsurface investigation probably due to the insignificant magnetic susceptibility contrast within the weathered layer and sediment, complexity in anomaly interpretation and the difficulties in obtaining useful quantitative information from its measurements (Burger et al. 1992).

However, with the availability of suite of robust data processing techniques such as vertical and horizontal derivatives,
Euler deconvolution and profile modeling that enhance characteristics of potential field data, information about the subsurface could be obtained from magnetic data, particularly when the data quality is good and measurement spacing is flexible.

Modomo Community in Ile-Ife, Southwestern Nigeria, is underlain by the Precambrian basement complex rocks where groundwater development via hand-dug wells and boreholes had been a major challenge (Alisiobi and Ako 2012; Oni 2014). Recent inventory/auditing of fifty-seven wells/boreholes within the community revealed $40.4 \%$ nonproductive holes (Eniola 2019). A detailed ground magnetic survey was therefore carried out within Modomo community with the objectives of delineating the major and interconnected geologic structures (fault/fracture/shear zones) and estimating the overburden thicknesses. The magnetic derived lineaments (structures) and overburden thicknesses were compared with the similar results from detailed resistivity survey and borehole information as a means of assessing the relevance of the magnetic method in groundwater investigation in a typical basement complex terrain.

\section{Description of the study area}

The Modomo community is located in Ile-Ife in Ife Central Local Government Area of Osun State, Southwestern Nigeria. It lies between Northings $828,400 \mathrm{mN}$ and $830,000 \mathrm{mN}$ and Eastings 664,000 mE and 665,600 mE of Zone $31 \mathrm{~N}$ (Minna datum) in the Universal Traverse Mercator coordinate system (Fig. 1). The topographic elevation ranges from 230 to $280 \mathrm{~m}$ (Fig. 1a) with a gently undulating topography in the southern and eastern parts and a gently sloping topography in the northern and western parts. The area is drained by River Asunle and its tributaries (Fig. 2). The drainage pattern within the study area is dendritic.

Modomo Community falls within the sub-equatorial south climatic region with two distinct seasons which include the rainy season from April to October with mean annual rainfall of about $1237 \mathrm{~mm}$ and the dry season that runs from November to March (Iloeje 1981).

The study area is underlain by the Precambrian basement complex rocks of southwestern Nigeria. The underlying rocks include granite gneiss and pegmatite of the Ife-Ilesha Schist Belt (Fig. 2). The granite gneiss is observed across the study area as low lying outcrops (Fig. 1a) while veins of pegmatite are visible along road cuts and channels created by erosion in the southwestern part of the study area. The overburden is made up of relatively thin clayey sand and clay. 


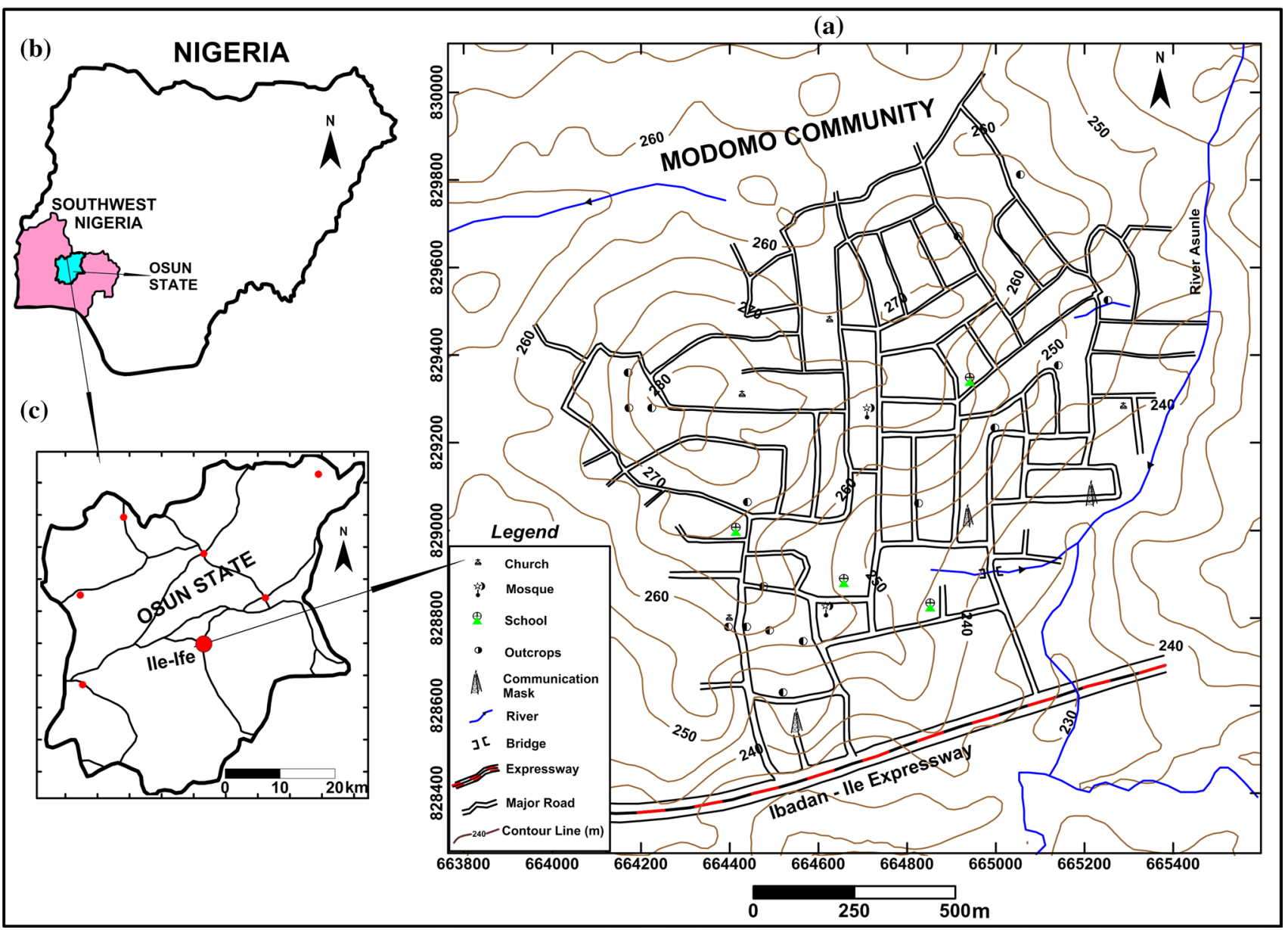

Fig. 1 Location map of a the study area b Nigeria showing Southwestern Region and Osun State and c Osun State showing Ile-Ife

\section{Materials and method of study}

\section{Reconnaissance field study and geophysical data acquisition}

Preliminary studies involving a review of previous works, acquisition of relevant maps (topographic and geologic maps) and site visitation to gather information on groundwater resource and development within the community, were carried out. Coordinates of road networks, rock outcrops and major landmark features such as church, mosques and schools were recorded and used to generate the base map for the study area (Fig. 3). Inventory of the available wells and boreholes within the study area was also carried out to establish their productivity status and the depth to which the wells and boreholes were drilled.

Ground magnetic survey was carried out along all access roads within the study area. Total field magnetic intensity (TMI) data were collected at station intervals of 10-100 m (but generally at $50 \mathrm{~m}$ ) (Fig. 3). The non-uniformity in the station interval was due to the built-up nature of the community and varying degrees of accessibility and cultural interference. Before the commencement of the data acquisition, a base station was established in a magnetically quiet environment within the study area where repeated readings were taken at intervals of about $30 \mathrm{~min}$ to monitor the trend of time varying component of the earth's total magnetic field (Diurnal variation) which were used to correct the field data for diurnal variation and offset by subtracting the base station magnetic measurement from a time-synchronized magnetic measurement along the occupied traverses. The residual magnetic data were quality checked and anomalous data (spikes) due to cultural effects removed.

\section{Magnetic data enhancement}

To assist the interpretation of the magnetic data, the residual magnetic data were reduced to the magnetic equator. Data enhancement techniques including second vertical derivative (SVD), total horizontal derivative (THD) and 3D Euler deconvolution were subsequently applied to the reduced to magnetic equator (RTE) data to map edges of structures and 


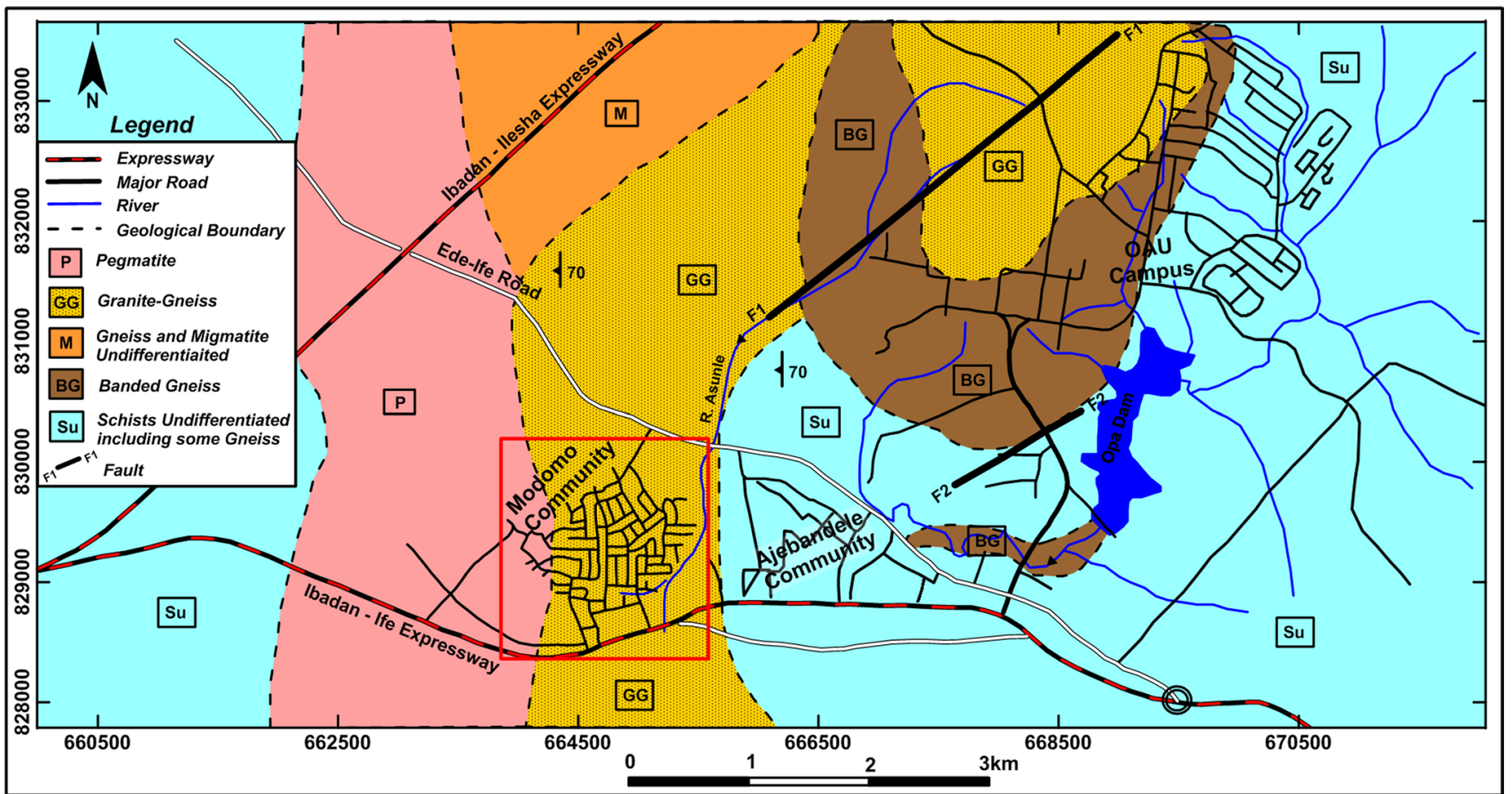

Fig. 2 Geological map of the study area (Modified after Geological Survey of Nigeria 1965; Boesse 1989)

estimate depth to the magnetic sources using the Geosoft software, Oasis Montaj ${ }^{\mathrm{TM}}$ v.6.4.2. Quantitative interpretation involving 2D magnetic modeling of selected profiles, across the study area, was also carried out for the estimation of overburden thicknesses or depths to magnetic sources. The enhancement techniques are briefly discussed.

\section{Reduction to the equator (RTE)}

Magnetic data at low and high magnetic latitudes are difficult to interpret because magnetic anomalies are displaced from their causative sources. Reduction to the equator is used in low magnetic latitudes, such as the study area $\left(I=-10.2^{\circ}\right)$, because it makes the magnetic field of the earth and magnetization of the magnetic sources to appear horizontal (as in the magnetic equator), centers the peaks of the magnetic anomalies over their sources and removes the asymmetry of the magnetic anomaly due to nonzero magnetic inclination. This makes the data easier to interpret, most especially with respect to target location.

\section{Total horizontal derivative (THD)}

Horizontal derivatives are magnetic vector data that give additional information concerning the directional variations of the total magnetic field (Nelson 1988; Christensen and
Dranfield 2002) and are essentially important when trying to map linear features such as fault zones/or dykes from magnetic data (Hogg 2004). Horizontal derivative maps are derivative products which reveal anomaly texture and highlight anomaly pattern discontinuities. The horizontal derivative of an anomaly field is calculated as the Pythagorean sum of the gradients in orthogonal directions. If $F(x, y)$ is the magnetic field, then the horizontal gradient magnitude $\operatorname{THD}(x, y)$ is given by Phillips (2000) as:

$\operatorname{THD}(x, y)=\sqrt{\left(\frac{\mathrm{d} F}{\mathrm{~d} x}\right)^{2}+\left(\frac{\mathrm{d} F}{\mathrm{~d} y}\right)^{2}}$.

This function peaks over (for thin dyke model) and at edges (for thick dyke model) of magnetic contacts on the assumptions that the regional magnetic field and source magnetizations are vertical among other assumptions (Phillips 2002).

\section{Second vertical derivative (SVD)}

Second vertical derivative map resolves or sharpens anomalies of small areal extent. Zero contours of second vertical derivative anomalies are used to outline the approximate boundaries of magnetic sources (Vacquier et al. 1951). 
Fig. 3 Base map of the study area showing the magnetic observation points

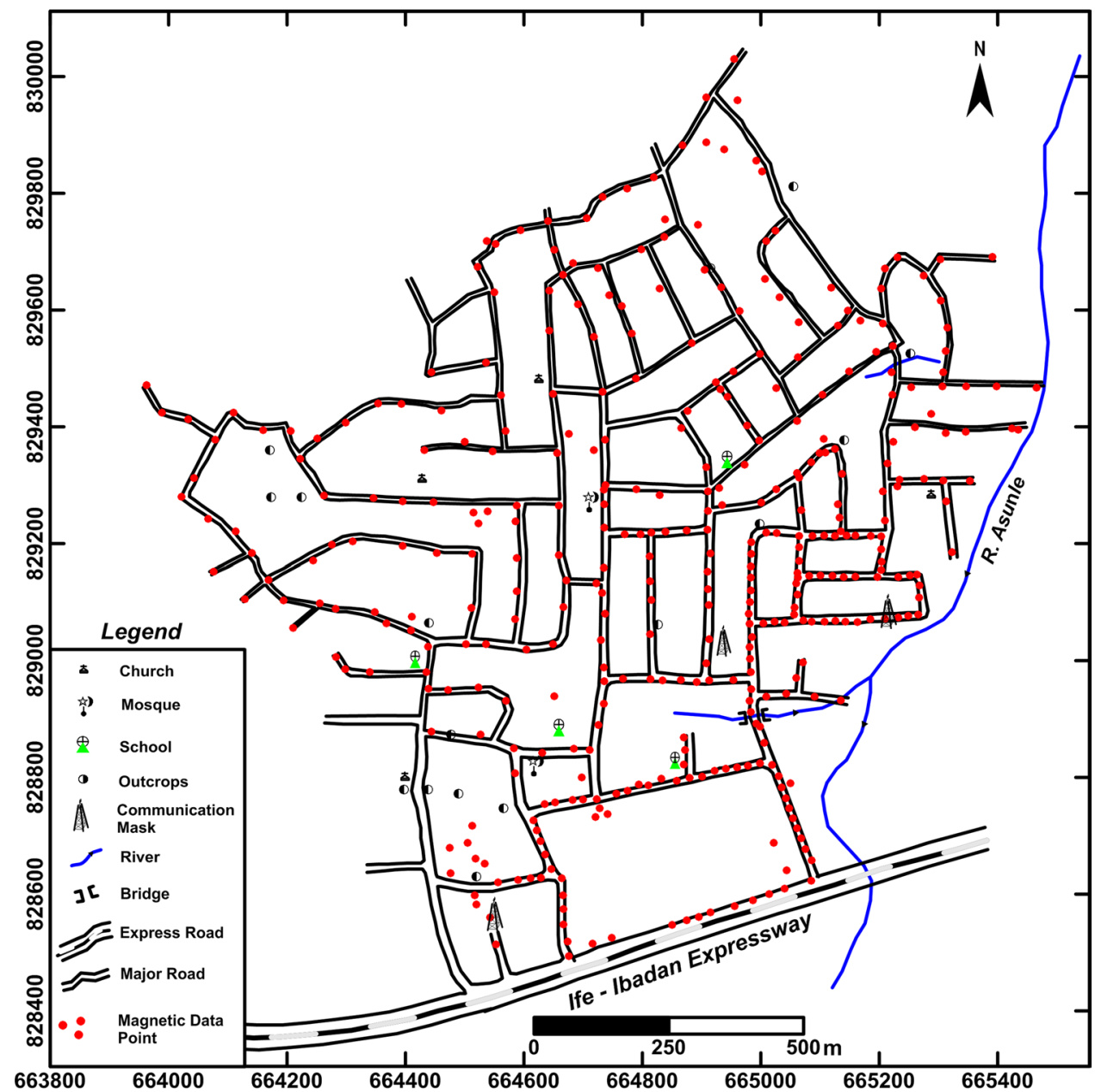

Second vertical derivative maps also enhance shallow sources at the expense of the deep sources. From Laplace's equation for potential field data, Eq. (2) defines the second vertical derivative of potential field $(F)$ data

$\frac{\mathrm{d}^{2} F}{\mathrm{~d} x^{2}}+\frac{\mathrm{d}^{2} F}{\mathrm{~d} y^{2}}+\frac{\mathrm{d}^{2} F}{\mathrm{~d} z^{2}}=0$

where $F=$ total magnetic intensity and $x, y$ and $z$ are the distances along the two horizontal and the vertical axes, respectively.

\section{D Euler deconvolution}

This data processing technique is based on the concept that anomalous magnetic fields of localized structures are homogeneous functions of the source coordinate and, therefore, satisfies Euler's homogeneity equation (Hood 1965; Thompson 1973; Reid et al. 1990). The technique operates on the data directly and provides a mathematical solution without recourse to any geological constraints. The application of Euler deconvolution has emerged as a powerful tool for direct determination of depth and probable source geometry in magnetic data interpretation (Barbosa et al. 1999; Muszala et al. 1999; Roy et al. 2000).

If a total field $(T)$ measured at a point $(x, y$ and $z$ ) has a base level of $b$ and derivatives $(\mathrm{d} T / \mathrm{d} x, \mathrm{~d} T / \mathrm{d} y$ and $\mathrm{d} T / \mathrm{d} z$ in the $x, y$ and $z$ directions), the 3D form of Euler's equation is defined by Reid et al. (1990) as:

$x \frac{\mathrm{d} T}{\mathrm{~d} x}+y \frac{\mathrm{d} T}{\mathrm{~d} y}+z \frac{\mathrm{d} T}{\mathrm{~d} z}+\eta T=x_{0} \frac{\mathrm{d} T}{\mathrm{~d} x}+y_{0} \frac{\mathrm{d} T}{\mathrm{~d} y}+z_{0} \frac{\mathrm{d} T}{\mathrm{~d} z}+\eta b$.

\section{D geological modeling of the subsurface}

Two-dimensional (2D) geologic models of the subsurface were generated with GM-SYS, Oasis montaj ${ }^{\mathrm{TM}}$ version 6.4.2 software based on Talwani and Heirtzler (1964); Talwani 
(1965) and Wen and Bevis (1987). Information on the overburden thicknesses (depths to magnetic source) was extracted from the models.

The magnetic maps (RTE, SVD, THD and Euler deconvolution solutions) were then interpreted qualitatively for identification of geologic structures (faults, geologic contacts and fracture zones) from which the structural map of the study area was generated. The interpretation results of the magnetic data (depth to basement bedrock and structural maps) were then correlated with the existing results (overburden thickness and structural maps) from 1D vertical electrical sounding (VES) and 2D resistivity structures and borehole information, for validation of the results.

\section{Results and discussion}

\section{Magnetic maps}

Figure 4 presents the residual magnetic field intensity (RMI) map of the study area. The amplitude of the RMI ranges from -414.5 to $349.9 \mathrm{nT}$. However, this map could not be accurately interpreted due to the effect of the nonzero magnetic inclination $\left(I=-10.2^{\circ}\right.$ for the study area) and was therefore reduced to the magnetic equator.

The reduced to the magnetic equator (RTE) map (Fig. 5) shows a magnetic field intensity that varies from -370.77 to 219.43 nT with series of high (positive) $(A-I)$ and low (positive and negative) (1-9) magnetic anomalies. The maximum (positive) magnetic intensity is observed in the northern and central parts of the study area, while the southern part is characterized by the minimum (negative) magnetic intensity. From this map (Fig. 5), the study area is divided into three magnetic zones (ZONES 1-3) using the variation and characteristic of the magnetic field intensity. ZONE 1 shows generally high (positive) magnetic response with magnetic intensities ranging from -13.7 to $219.43 \mathrm{nT}$. The central part (ZONE 2) is characterized by variable magnetic responses with a mixture of moderate to high magnetic intensities. The magnetic intensity values range from -24.69 to $219.43 \mathrm{nT}$. The southern part (ZONE 3) has low (negative) magnetic response with magnetic intensities ranging from -24.69 to $-370.77 \mathrm{nT}$.
Fig. 4 Residual magnetic intensity (RMI) map of the study area

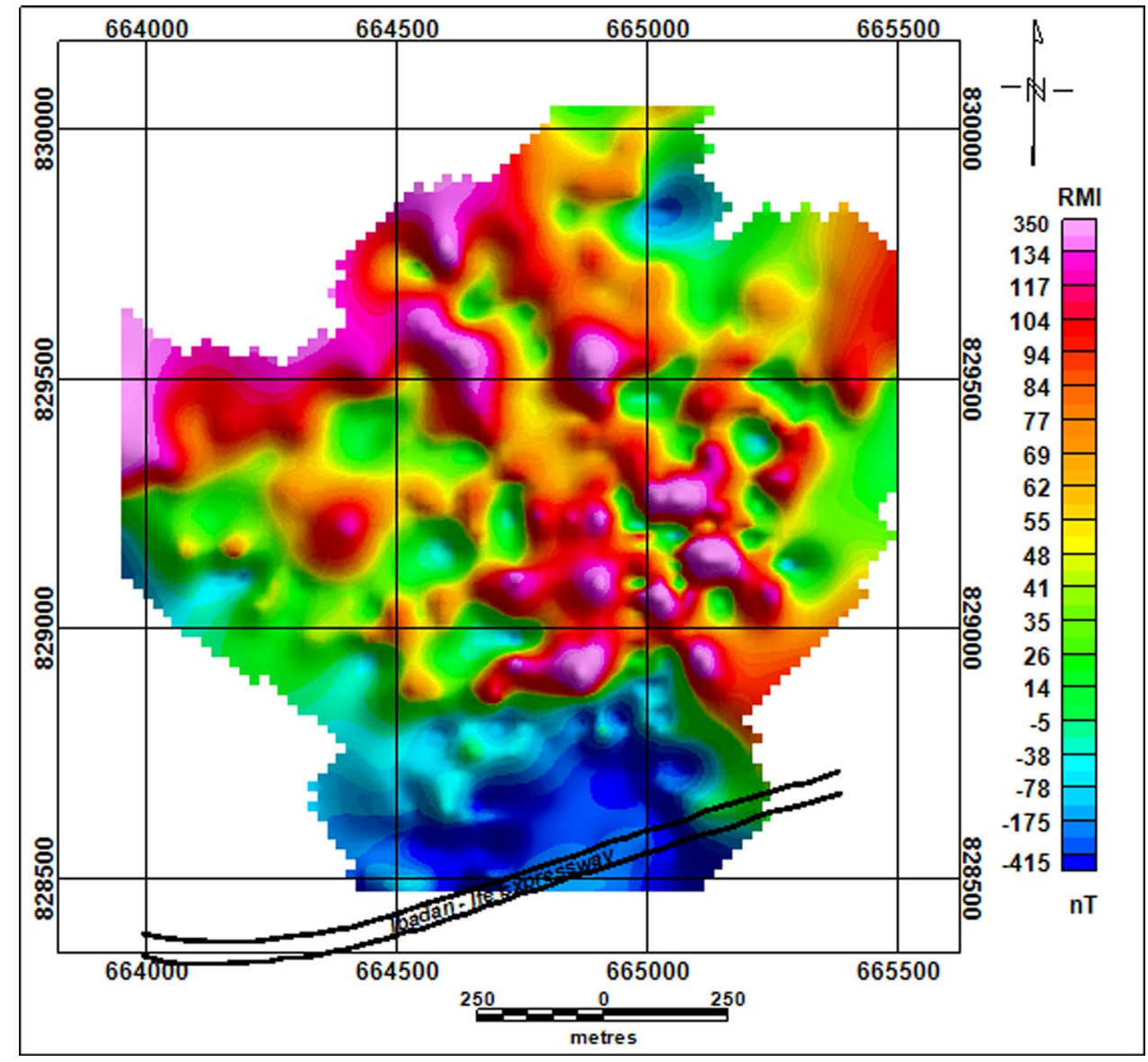


Fig. 5 Reduced to the magnetic equator (RTE) map of the study area

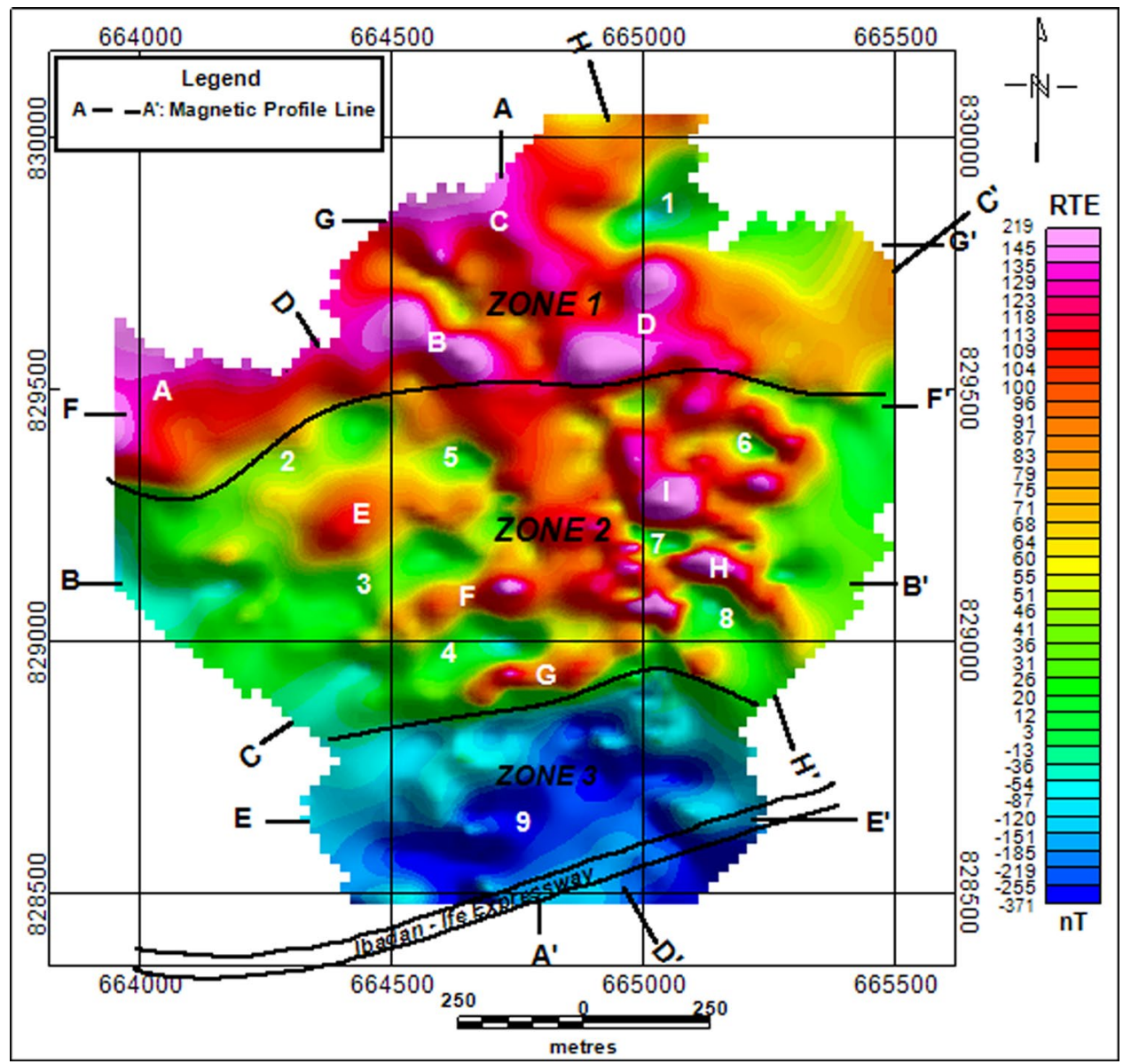

This kind of variation in magnetic intensity could mean variation in lithology, discontinuities in the basement rock (caused by faulting, fracturing or jointing) or an indication of the basement relief. From the geologic map of the study area (Fig. 2) and direct field observations during data acquisition, the study area is mainly underlain by one rock type (granite gneiss), while an insignificant part is underlain by pegmatite. Therefore, variations in magnetic intensity within the study area could only be an indication of basement relief and discontinuities (fractures, faults and joints) in the rocks underlying the study area rather than geology (lithological variation). In the magnetic ZONE 1, there are four prominent high (positive) magnetic anomalies (A, B, C and D) with B and C trending NW-SE while $A$ and $D$ trend $E-W$ direction. Other observable anomaly within this zone is labeled 1 and is characterized by short wavelength low magnetic intensity. ZONE 2 is characterized by several elongated high positive $(\mathrm{E}-\mathrm{H})$ and low (positive) (2-8) magnetic anomalies, particularly in the western half, with ENE-WSW orientation. The magnetic low (2, 3 and 4) and high (A, E, F and G) anomalies are sandwiched between one another and are of the same trend. A prominent elongated low (negative) magnetic anomaly, labeled 9 which trends approximately E-W direction, is observed within ZONE 3.

The locations and orientations of the subsurface structures were clearly mapped on the structure enhanced maps (Figs. 6, 7, 8). The total horizontal derivative (THD) map (Fig. 6) reveals the contact locations as peak amplitude anomalies with values ranging from $0.111 \mathrm{nT} / \mathrm{m}$ to 3.70 $\mathrm{nT} / \mathrm{m}$. The anomaly maxima, highlighted on the map as black lines, represent the identified contact locations. The orientations of the lineaments are E-W, ENE-WSW, NW-SE and NE-SW. Most of the identified THD lineaments were defined by the $0 \mathrm{nT} / \mathrm{m}^{2}$ contour lines on the second vertical derivative (SVD) map (Fig. 7) whose amplitudes vary 
Fig. 6 Total horizontal derivative (THD) map of the study area showing identified lineaments with black lines

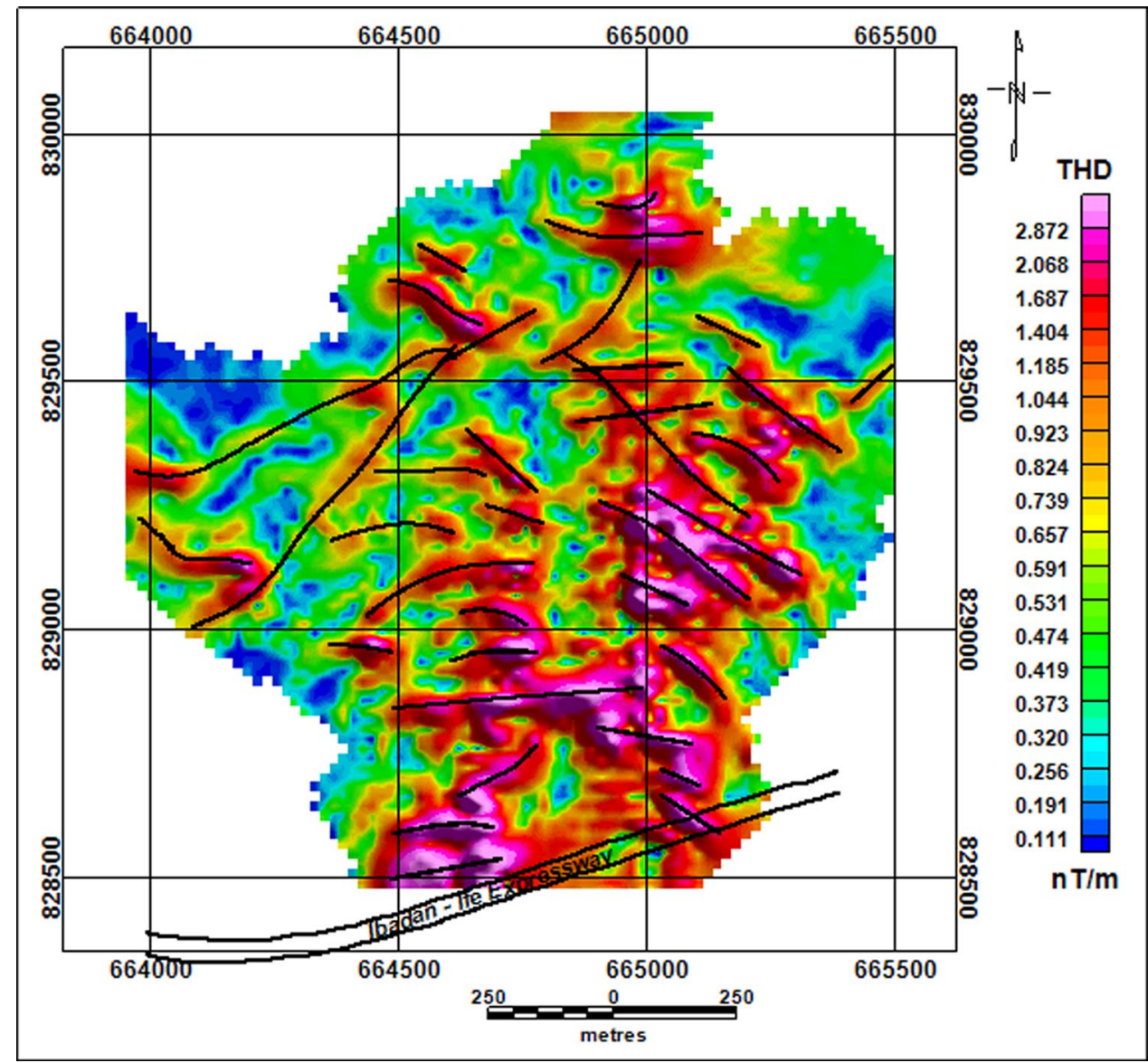

between -0.180 and $0.169 \mathrm{nT} / \mathrm{m}^{2}$. Lineaments derived from the SVD map were highlighted with black lines. The discontinuous nature of the lineaments identified on the derivative maps (Figs. 6, 7) is typical of fractures, faults or joints and not geologic contacts/or boundaries.

Figure 8 shows the 3D Euler deconvolution map of the study area. This technique was adopted to map lineament locations and also estimate depth to the top of the magnetic sources (structures). The best clustered solution was achieved using a structural index, $\eta=0.5$, window sizes of 10 and tolerance of 20. According to Hsu (2002), the adopted structural index $(\eta=0.5)$ is typical of contacts with small depth extent (Table 1). The depth range of identified structures varied from $0 \mathrm{~m}$, on rock outcrop to $100 \mathrm{~m}$ with 15-50 $\mathrm{m}$ range constituting the predominant depth of lineament occurrence. This shows the near surface nature of the structures. The orientations of the structures are E-W, ENE-WSW, NE-SW and NW-SE as earlier observed on the derivative maps.
It is generally observed that most of the structures are concentrated in the northern, southern and western parts of the study area while the eastern part is sparse in structure. Identified lineaments from the derivatives maps were superimposed on the Euler solution (Fig. 9). The superimposition shows significant correlations of lineaments, especially in the southern, western and northern parts of the study area where the THD and SVD derived lineaments fell mostly on and at the edge of the Euler solutions. This shows the genuineness of most of the structures mapped by these techniques. However, in the eastern part of the study area, the 3D Euler deconvolution technique shows sparse solution clusters, whereas the derivatives mapped some suspected lineaments.

Structure map (Fig. 10) of the study area was evolved from the synthesis of the THD, SVD and Euler deconvolution derived structures such that consistent structures (i.e., lineaments/structures that correlated across at least two of the maps) were classified as genuine structures and presented 
Fig. 7 Second vertical derivative (SVD) map of the study area showing identified lineaments with black lines

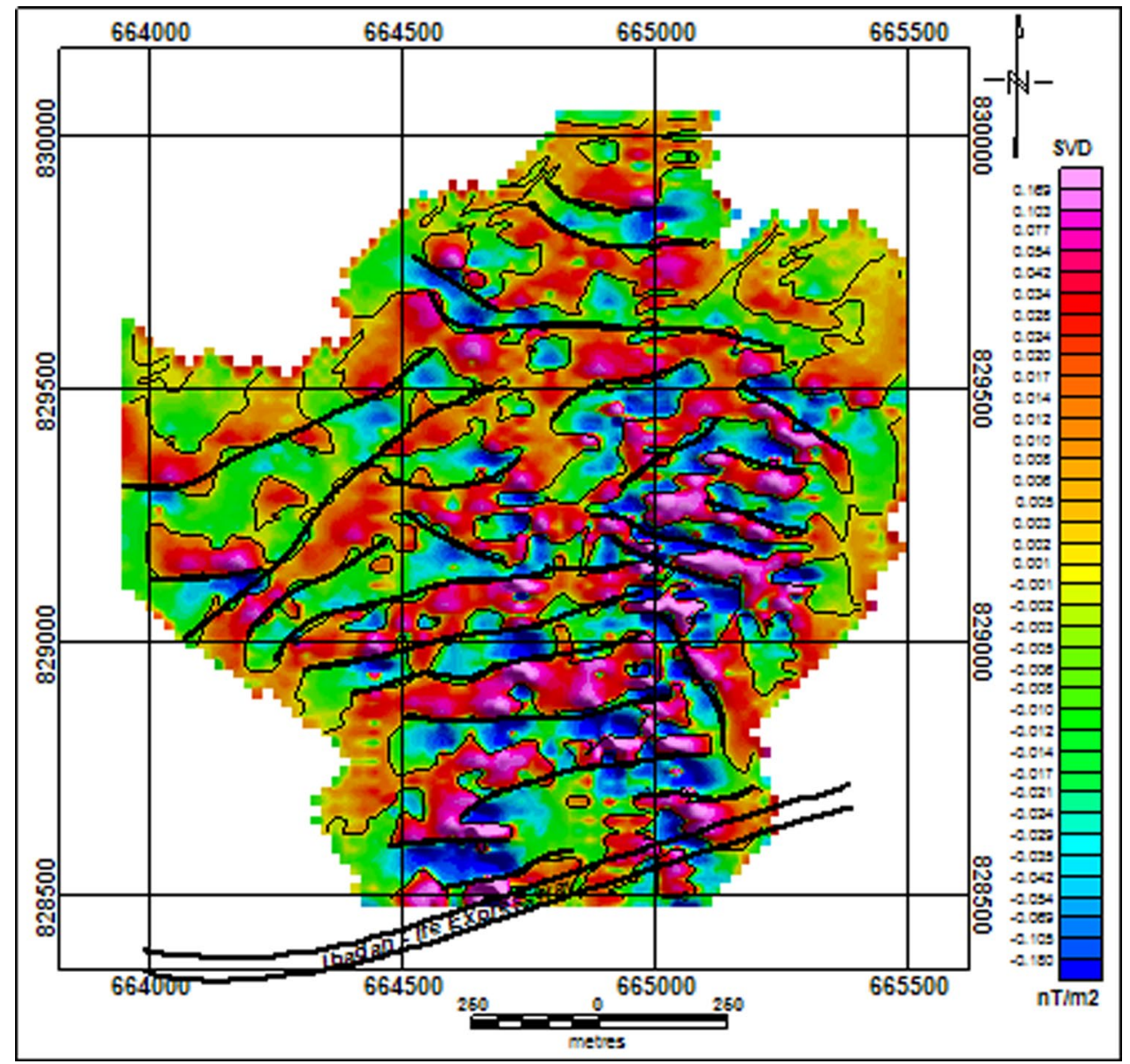

as continuous lines while others were classified as suspected lineaments/structures and presented as dotted lines. Twentyfour (24) lineaments, twenty-one (A-U) genuine and three suspected (1-3) lineaments/structures were identified within the study area. The lengths of the lineaments varied from 150 to $777 \mathrm{~m}$, for $\mathrm{P}$ and $\mathrm{L}$, respectively. The orientations of the structures are approximately E-W (B, E, J, O, P and U), ENE-WSW (A, H, I and Q), ESE-WNW (M, R, S and T), NW-SE (C and 1), NE-SW (D, K, L and 3) and NNW-SSE (F, 1 and 2) (Fig. 10). Significant numbers of the lineaments are concentrated in the northern half of the study area. For structures with large width/depth extent (thick dyke model) the Euler solution, the peak amplitude THD anomaly and SVD zero contour lines define the edges/boundaries while for contacts with small width/depth extent (thin dyke model), the contact location is defined (Table 1; Phillips 2002; Ndougsa-Mbarga et al. 2012). The near parallel nature and about equal length extent of lineaments $\mathrm{K}$ and $\mathrm{L} ; \mathrm{E}$ and $\mathrm{G}$ and $\mathrm{H}$ and I (Fig. 10) suggest that the lineaments could be boundaries of three different structures or are separate structures formed from the same tectonic event (syn-tectonic). It is suspected that the E-W striking stream, flowing into the Asunle river in the southeastern part of the study area, may have been structurally controlled by the lineament labeled $\mathrm{E}$.

\section{Profile modeling and overburden thickness estimation}

Eight profiles $\left(A-A^{1}, B-B^{1}, C-C^{1}, D-D^{1}, E-E^{1}, F-F^{1}, G-G^{1}\right.$ and $\mathrm{H}-\mathrm{H}^{1}$ ) were generated across the RTE map (Fig. 5) for 2D magnetic subsurface modeling. The modeling was carried out to estimate the overburden thicknesses/depths to the magnetic basement. Typical profiles and 2D magnetic 
Fig. 8 3D Euler deconvolution solution map (using structural index $(\eta)=0.5$, window size of 10 and tolerance of 20)

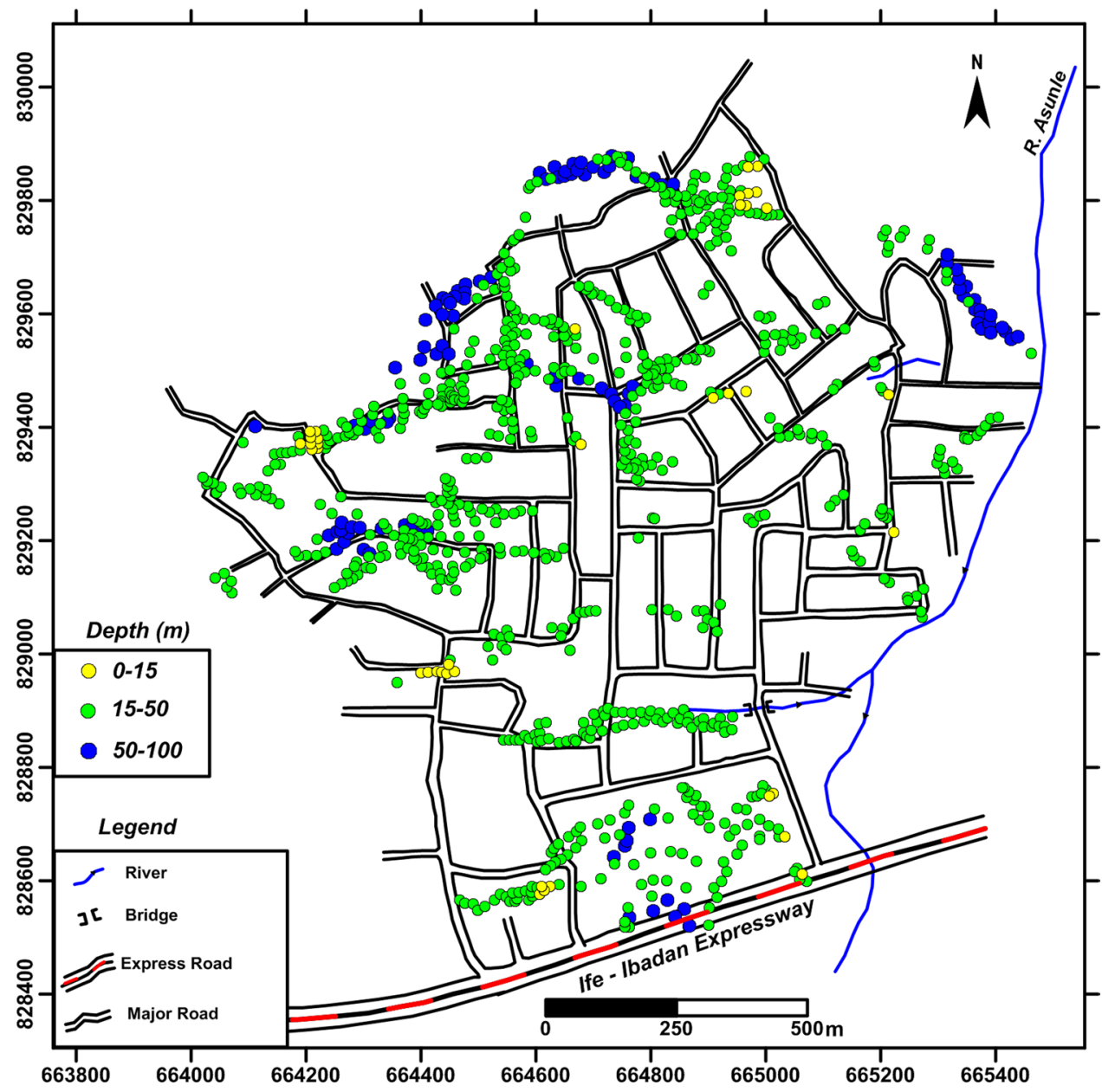

subsurface models obtained along the selected profiles are displayed in Fig. 11a, b. The depth to the magnetic basement ranges from 0 to $75 \mathrm{~m}$ with an average depth of $21.78 \mathrm{~m}$.

Table 1 Structural index and their corresponding magnetic models (After Hsu 2002)

\begin{tabular}{lll}
\hline $\begin{array}{l}\text { Structural } \\
\text { index }(\eta)\end{array}$ & Magnetic model & Euler depth position \\
\hline 0.0 & Contact with large depth extent & At top and edge \\
0.5 & Contact with small depth extent & $\begin{array}{l}\text { At top and edge } \\
1.0\end{array}$ \\
Thin prism with large depth extent & $\begin{array}{l}\text { At top and center, } \\
\text { or at edge and half } \\
\text { throw }\end{array}$ \\
2.0 & Vertical or horizontal cylinder & $\begin{array}{l}\text { At center } \\
\text { At center }\end{array}$ \\
\hline
\end{tabular}

Most of the modeled structures (fault/fracture zone) show vertical/near vertical dip.

Figure 12 shows the magnetic derived overburden thickness map of the study area, generated from extracted thicknesses from the modeled profiles. The magnetic overburden thickness ranges from 0 to $75 \mathrm{~m}$. The map shows that $54.5 \%$ of the study area, which encompasses the central and southern parts, has overburden thicknesses ranging from 0 to $20 \mathrm{~m}$ while the northern part shows overburden thicknesses ranging from 20 to $75 \mathrm{~m}$. However, some portions of the southern part of the study area also show significant overburden thickness ranging from 20 to $75 \mathrm{~m}$. 
Fig. 9 Map showing the 3D Euler solution and superimposed THD and SVD derived lineaments

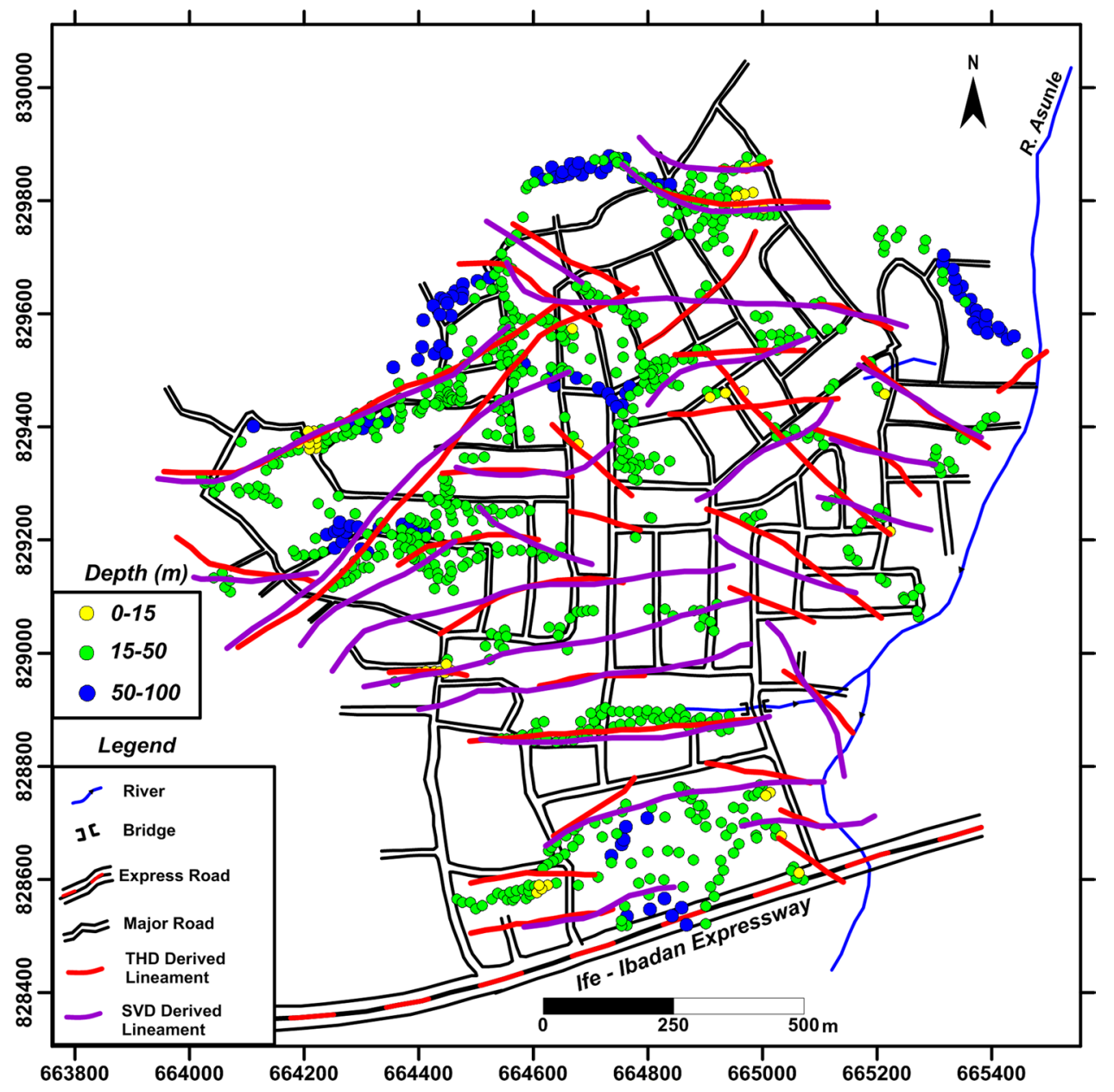

\section{Results validation}

Adediran (2019) carried out a detailed geophysical investigation involving 2D resistivity imaging (adopting the dipole-dipole array) and 1D vertical electrical sounding (VES) using the Schlumberger array within the current study area. Figure 13 shows the structure map obtained from the study. Superimposed on this map are the magnetic lineaments in Fig. 10.

Nine (9) resistivity survey derived structure zones, characterized by near vertical/vertical low resistivity discontinuity between a very resistive host basement rock, which are labeled R1-9 (Fig. 13), show significant correlation with the magnetic lineaments. Resistivity structures R1, R2, R3 and R8 correlated with magnetic structures A, B, E and 3, respectively. However, the correlation between resistivity structure R5 and magnetic lineaments $\mathrm{K}$ and L shows that
$\mathrm{R} 5$ is completely located between $\mathrm{K}$ and $\mathrm{L}$ while displaying the same structure geometry. Segment of R5 represented with continuous lines to denote where the structure was clearly identified correlated with the continuous segments of the magnetic lineaments $\mathrm{K}$ and $\mathrm{L}$. The suspected segment of the resistivity structure R5 in dashed line segments also correlated with the suspected segment of the magnetic lineaments.

As earlier inferred in the discussion of the magnetic structure map, lineaments $\mathrm{K}$ and $\mathrm{L}$ are suspected to be boundaries of a mega structure R5. The width of the magnetic lineaments (distance between lineaments $\mathrm{K}$ and $\mathrm{L}$ ) is much wider than the width of the corresponding resistivity structure as previously observed by Olorunfemi and Oni (2019). As observed by these authors, the direction of displacement between the magnetic and resistivity structures is the direction of dip of the structure. This means 


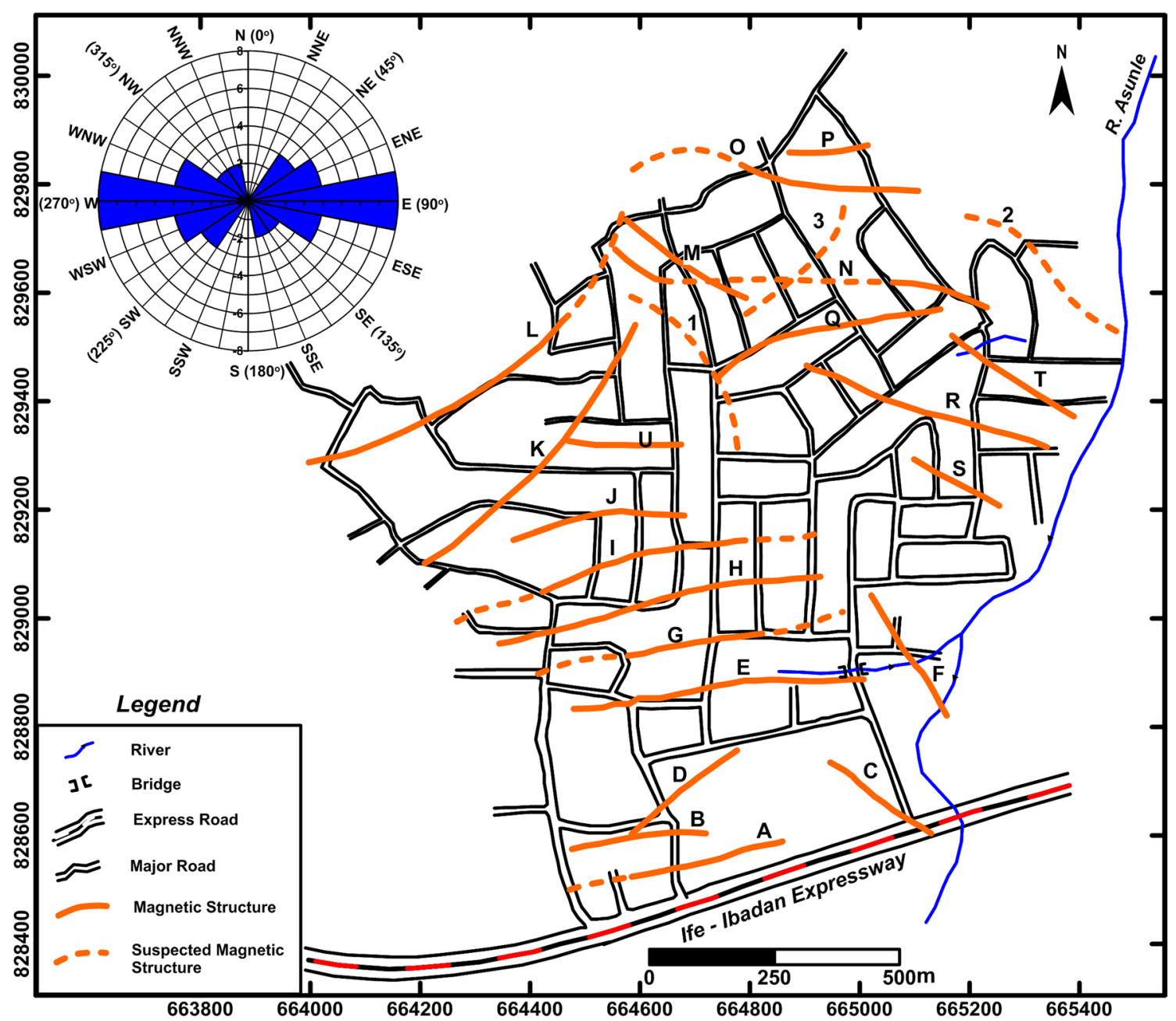

Fig. 10 Structure map of the study area generated from synthesis of 3D Euler deconvolution, SVD and THD derived lineaments

that structure R5 dips northwesterly. This dip direction is corroborated by the direction of displacement of the Euler solution of the same structure (Fig. 8). The solutions of 50-100 m depth range, denoted with blue color, are displaced in the northwest relative to solutions obtained for shallower $(15-50 \mathrm{~m})$ depth range. The summary of the magnetic derived lineaments and their corresponding 2D resistivity derived structures are contained in Table 2.

For the overburden thickness estimation, Fig. 14a, b shows the magnetic derived overburden and geoelectric derived overburden thickness maps, respectively. The magnetic overburden thickness ranges from 0 to $75 \mathrm{~m}$ with $80.50 \%$ of the study area showing thicknesses that are less than $30 \mathrm{~m}$, while the geoelectric overburden thickness ranges from 0 to $30 \mathrm{~m}$. This disparity in overburden thickness estimation is thought to be due to the different physical properties contrasts (magnetic susceptibility and resistivity of earth material), these methods are responsive to. Also, the magnetic method measures depth to magnetic basement which is usually deeper than the geologic/geoelectric basement which the electrical resistivity method is responsive to. Despite the disparity in the estimated overburden thicknesses by the two methods, the two methods show that more than $50 \%$ of the study area has overburden thicknesses ranging from 0 to $20 \mathrm{~m}$. On both maps, the northern part of the study area has the thickest overburden, 

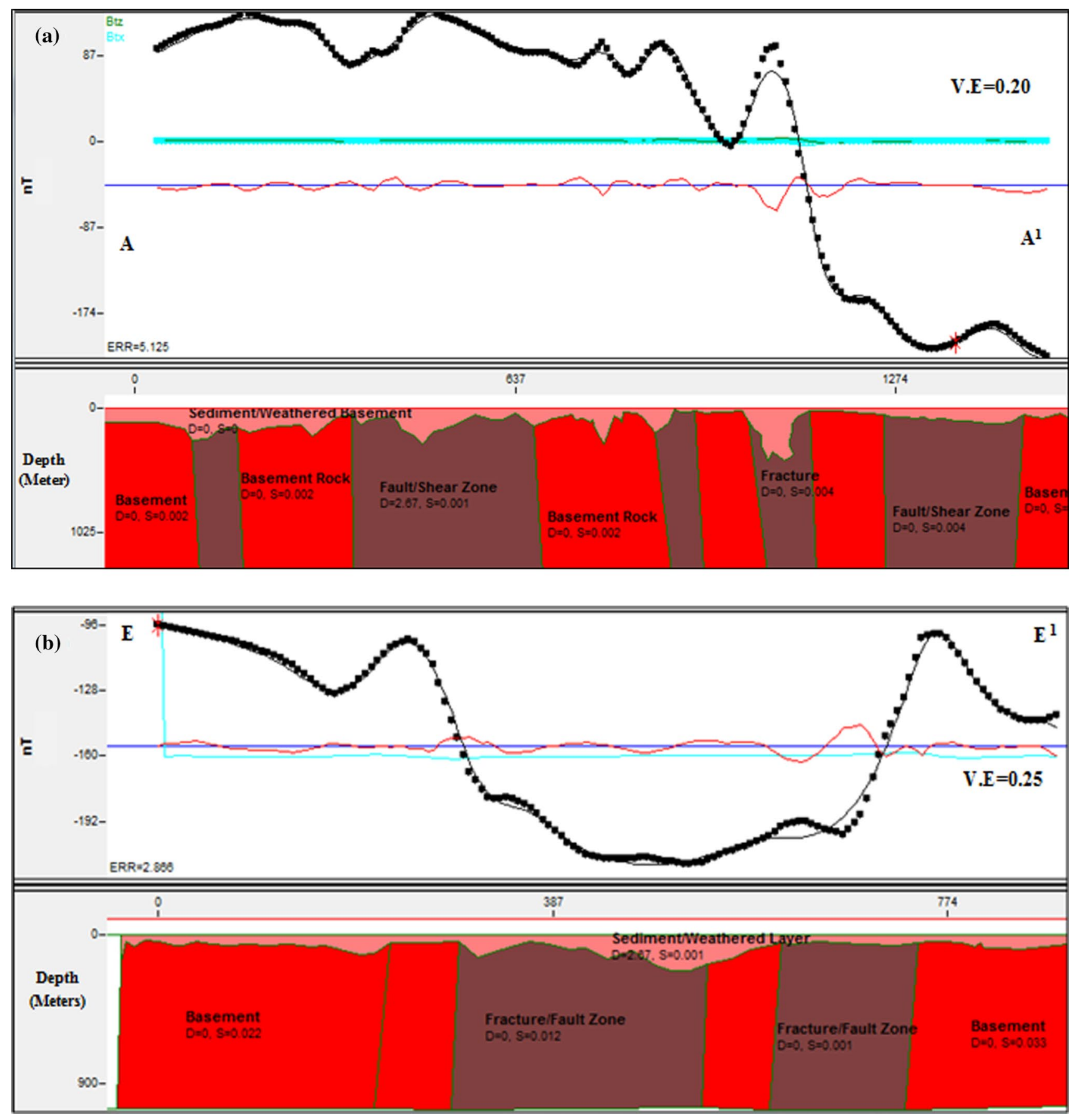

Fig. 11 a Magnetic profile and 2D subsurface magnetic model along $\mathrm{A}-\mathrm{A}^{1}$ profile line, $\mathbf{b}$ magnetic profile and 2D subsurface magnetic model along $\mathrm{E}-\mathrm{E}^{1}$ profile line 
Fig. 12 Magnetic overburden thickness map with superimposed well locations

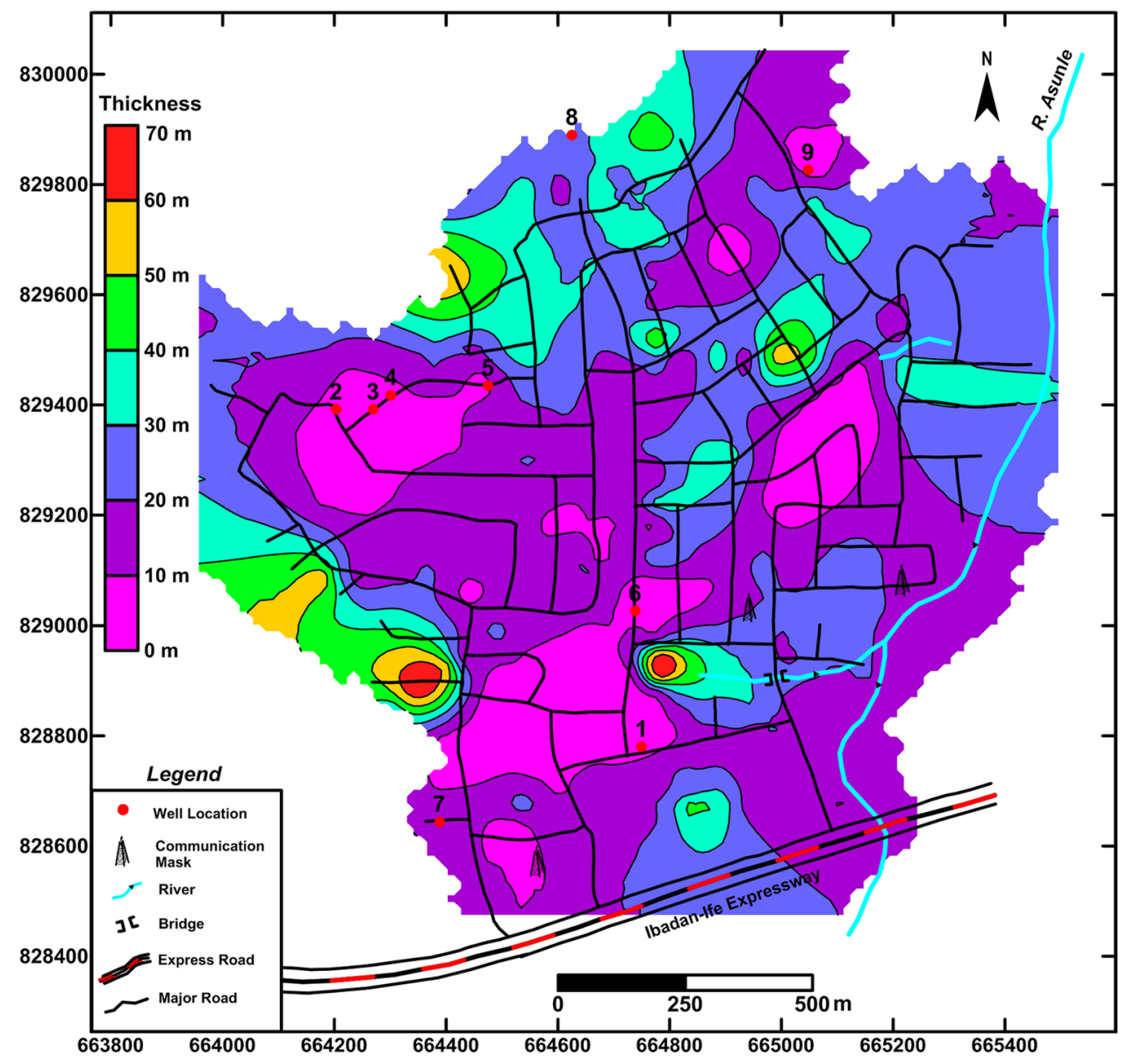

though some isolated portions of the southern part also show overburden thicknesses that are more than $20 \mathrm{~m}$. Generally, both maps display significant correlation.

The depths to rock head obtained from boreholes/wells were compared with the depth to magnetic basement derived from the 2D magnetic models in (Table 3). The table shows that the magnetic derived overburden thicknesses are generally higher (6.85-59.80\%) than the thicknesses obtained at some well locations $(1,4,5,6,7,8$ and 9) and lower (24.56-26.50\%) at other well locations (2 and 3). However, the overburden thickness range falls between 0 and $20 \mathrm{~m}$ in both cases which is in agreement with the $1 \mathrm{D}$ resistivity derived overburden thicknesses.

\section{Conclusion}

Detailed ground magnetic survey was carried out in a typical basement complex terrain of Modomo in Southwestern Nigeria. In such terrain, groundwater aquifers are the weathered layer and or fractured basement column. Delineating these aquifer units and determining their geometries 


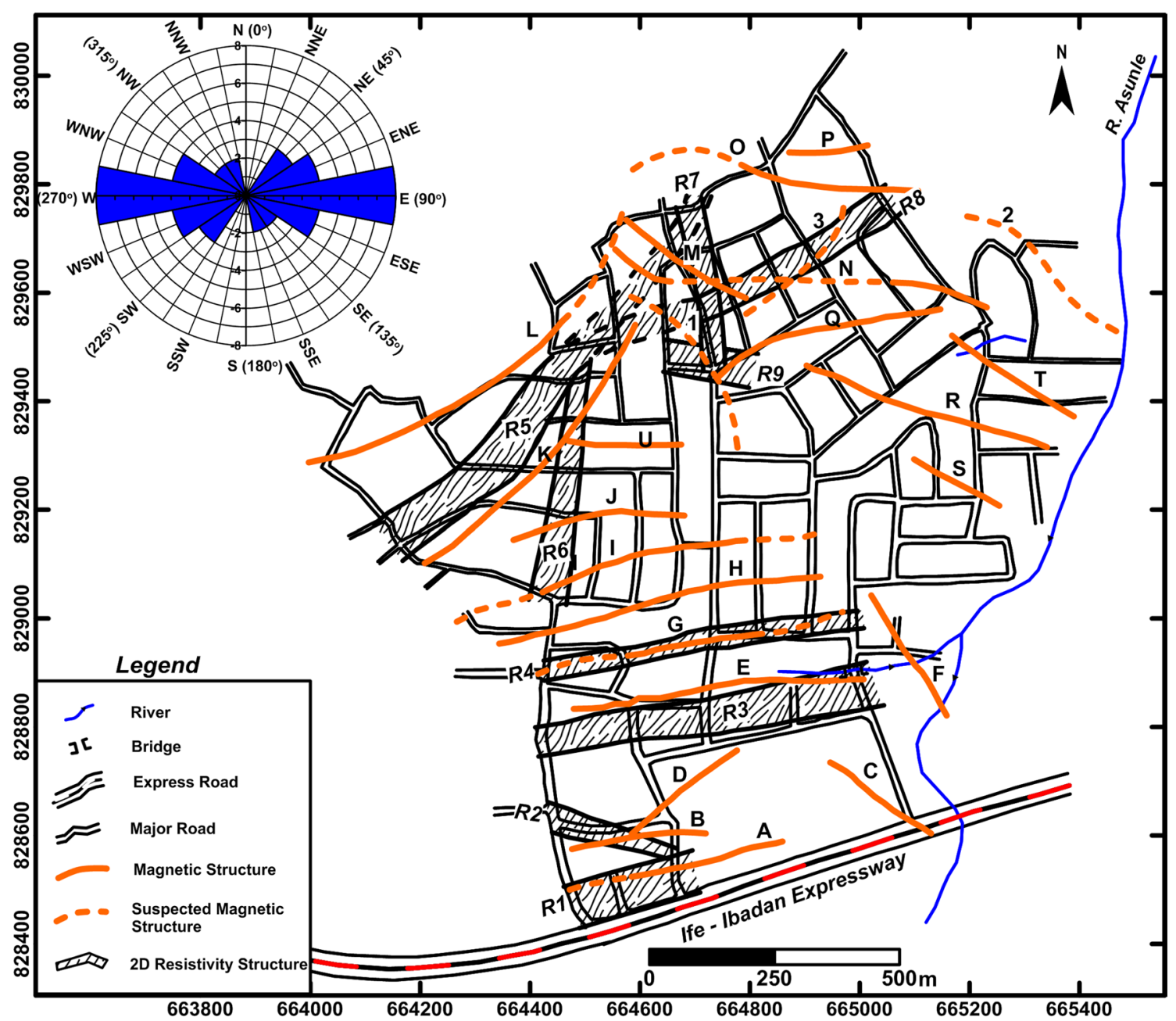

Fig. 13 Composite structure map of the study area (Modified from Adediran 2019)

(lateral and vertical extents) are required in groundwater development in a basement complex terrain. The electrical resistivity method is often engaged in predrilling groundwater investigation while the magnetic method is rarely used. However, with a suite of data enhancement techniques now available for the processing and interpretation of potential field data, comparable results and information about the subsurface aquifers, typically obtained from resistivity method, could be achieved with the magnetic method.

The results of a detailed ground magnetic survey in the study area identify geologic structures that are corroborated by $2 \mathrm{D}$ resistivity images. The study also showed that overburden thicknesses that are comparable with 1D VES derived overburden thicknesses can be estimated from magnetic survey. It is therefore concluded that the magnetic method can be reliably used for overburden thickness estimation and structure mapping and hence very relevant in groundwater investigation in a typical basement complex terrain. 
Table 2 Summary of the magnetic and resistivity derived lineaments

\begin{tabular}{|c|c|c|c|c|c|c|c|}
\hline \multirow{2}{*}{$\begin{array}{l}\text { Magnetic } \\
\text { derived linea- } \\
\text { ments }\end{array}$} & \multicolumn{3}{|l|}{ Real lineaments } & \multirow{2}{*}{$\begin{array}{l}\text { Magnetic } \\
\text { derived linea- } \\
\text { ments }\end{array}$} & \multicolumn{3}{|c|}{ Suspected/inferred lineaments } \\
\hline & $\begin{array}{l}\text { Corresponding resistiv- } \\
\text { ity derived lineaments }\end{array}$ & $\begin{array}{l}\text { Lineament } \\
\text { length }(\mathrm{m})\end{array}$ & $\begin{array}{l}\text { Lineaments } \\
\text { dip direction }\end{array}$ & & $\begin{array}{l}\text { Corresponding resistiv- } \\
\text { ity derived lineaments }\end{array}$ & $\begin{array}{l}\text { Lineament } \\
\text { length }(\mathrm{m})\end{array}$ & $\begin{array}{l}\text { Lineaments } \\
\text { dip direction }\end{array}$ \\
\hline A & $\mathrm{R} 1$ & 405 & Vertical & 1 & R7/R8/R9 & 365 & - \\
\hline B & $\mathrm{R} 2$ & 255 & - & 2 & - & 362 & - \\
\hline $\mathrm{C}$ & - & 230 & - & 3 & $\mathrm{R} 8$ & 272 & - \\
\hline $\mathrm{D}$ & - & 248 & - & & & & \\
\hline $\mathrm{E}$ & R3 & 540 & Vertical & & & & \\
\hline $\mathrm{F}$ & - & 263 & - & & & & \\
\hline G & $\mathrm{R} 4$ & 575 & Vertical & & & & \\
\hline $\mathrm{H}$ & - & 607 & - & & & & \\
\hline I & R6 & 678 & - & & & & \\
\hline $\mathrm{J}$ & R6 & 325 & - & & & & \\
\hline K & $\mathrm{R} 5$ & 597 & NW & & & & \\
\hline $\mathrm{L}$ & R5 & 777 & NW & & & & \\
\hline M & $\mathrm{R} 5 / \mathrm{R} 7 / \mathrm{R} 8$ & 271 & - & & & & \\
\hline $\mathrm{N}$ & $\mathrm{R} 7 / \mathrm{R} 8$ & 705 & Vertical & & & & \\
\hline $\mathrm{O}$ & - & 544 & - & & & & \\
\hline $\mathrm{P}$ & - & 150 & - & & & & \\
\hline Q & R9 & 435 & Vertical & & & & \\
\hline $\mathrm{R}$ & - & 468 & & & & & \\
\hline S & - & 185 & & & & & \\
\hline $\mathrm{T}$ & - & 270 & & & & & \\
\hline $\mathrm{U}$ & R6 & 215 & & & & & \\
\hline
\end{tabular}

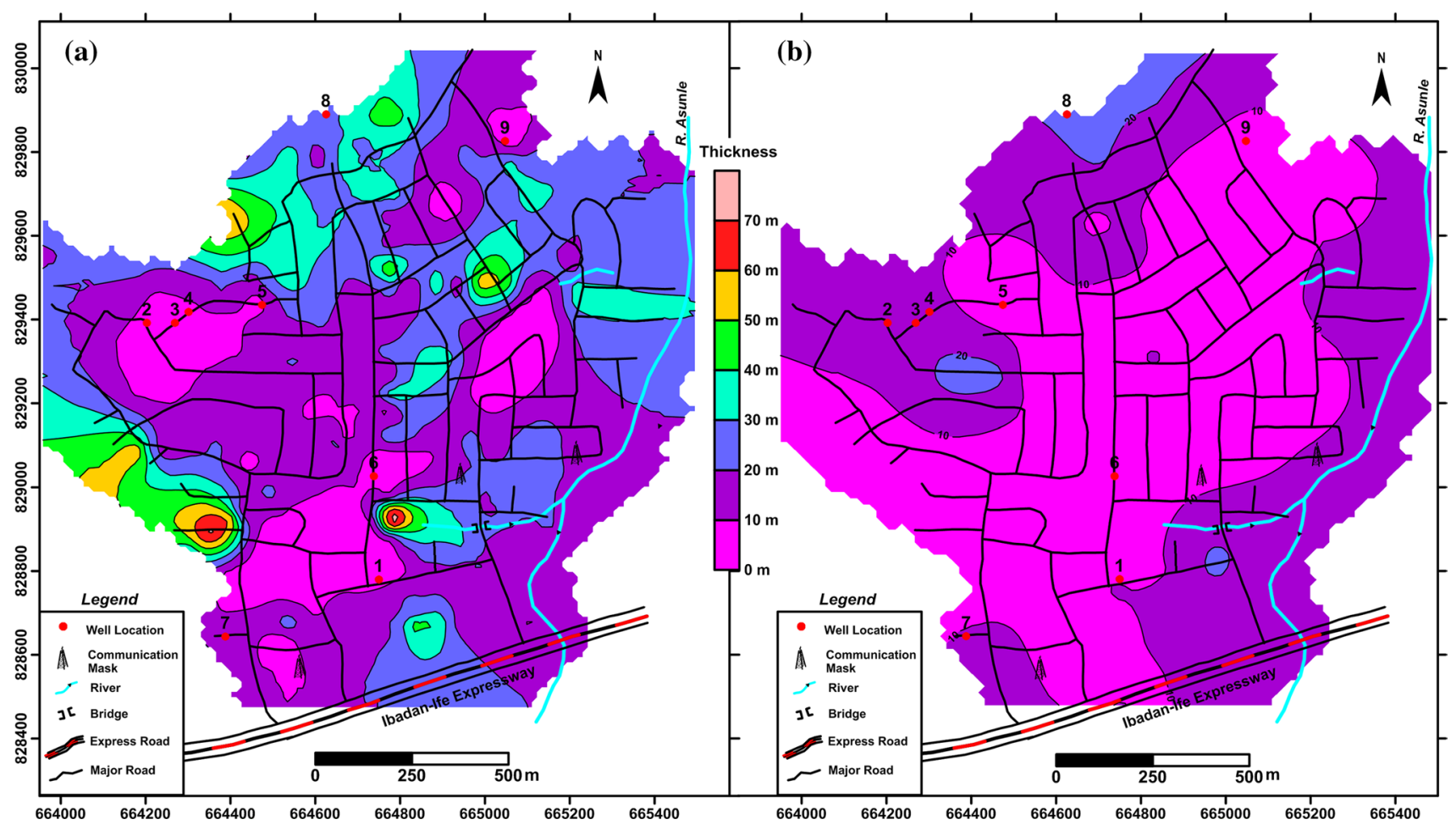

Fig. 14 Overburden thickness maps derived from a 2D magnetic models and b 1D VES interpretation result 
Table 3 Depth to rock head derived from borehole, magnetic overburden thicknesses and the percentage deviation

\begin{tabular}{lllllc}
\hline S/N & $X$ & $Y$ & $\begin{array}{l}\text { Borehole depth to rock } \\
\text { head }(\mathrm{m})(A)\end{array}$ & $\begin{array}{l}\text { Magnetic overburden } \\
\text { thicknesses }(\mathrm{m})(B)\end{array}$ & $\begin{array}{c}\text { \% Deviation } \\
\text { of } B \text { from } A\end{array}$ \\
\hline 1 & 664,749 & 828,778 & 5.48 & 7.35 & 34.12 \\
2 & 664,203 & 829,390 & 6.00 & 4.41 & -26.50 \\
3 & 664,266 & 829,393 & 6.80 & 5.13 & -24.56 \\
4 & 664,300 & 829,417 & 6.80 & 7.86 & 15.59 \\
5 & 664,472 & 829,435 & 6.80 & 8.61 & 26.62 \\
6 & 664,738 & 829,027 & 5.10 & 8.15 & 59.80 \\
7 & 664,386 & 828,641 & 10.00 & 14.08 & 40.80 \\
8 & 664,625 & 829,889 & 27.1 & 29.40 & 8.49 \\
9 & 665,031 & 829,807 & 8.61 & 9.22 & 6.85 \\
\hline
\end{tabular}

Funding No funding was received for this study.

\section{Compliance with ethical standards}

Conflict of interest The authors declare that they have no conflict of interest.

Ethical standard Authors adhered to all form of ethical standard.

Informed consent Informed consent was obtained from all individual participants included in the study.

Open Access This article is licensed under a Creative Commons Attribution 4.0 International License, which permits use, sharing, adaptation, distribution and reproduction in any medium or format, as long as you give appropriate credit to the original author(s) and the source, provide a link to the Creative Commons licence, and indicate if changes were made. The images or other third party material in this article are included in the article's Creative Commons licence, unless indicated otherwise in a credit line to the material. If material is not included in the article's Creative Commons licence and your intended use is not permitted by statutory regulation or exceeds the permitted use, you will need to obtain permission directly from the copyright holder. To view a copy of this licence, visit http://creativecommons.org/licenses/by/4.0/.

\section{References}

Acworth I (2001) The electrical image method compared with resistivity sounding and electromagnetic profiling for investigation in area of complex geology: a case study from groundwater investigation in a weathered crystalline rock environment. Explor Geophys 32:119-128

Adediran TA (2019) An evaluation of the groundwater potential of Modomo, Ile-Ife, using integrated 1D and 2D electrical resistivity imaging techniques. Thesis, Obafemi Awolowo University, Ile-Ife, Nigeria

Alisiobi AR, Ako BD (2012) Groundwater investigation using combined geophysical methods. In: Proceedings of AAGP annual convention and exhibition, California, April, 22-25, pp 1-19

Babu HVR, Rao NK, Kumar VV (1991) Bedrock topography from magnetic anomalies - an aid for groundwater exploration in hardrock terrains (short note). Geophysics 56(7):1051-1054

Barbosa VCF, Silva JBC, Medeiros WE (1999) Stability analysis and improvement of structural index estimation in Euler deconvolution. Geophysics 64:48-60
Boesse JM (1989) Geological map of the Obafemi Awolowo University campus. Thesis, Obafemi Awolowo University, Ile-Ife, Nigeria

Burger HR, Sheehan AF, Jones CH (1992) Introduction to applied geophysics: exploring the shallow subsurface. W. W. Norton \& Company, London

Chirindja FJ, Dahlin T, Juizo D (2017) Improving the groundwaterwell siting approach in consolidated rock in Nampula Province, Mozambique. Hydrogeol J 25:1423-1435

Christensen A, Dransfield M (2002) Airborne vector magnetometry over banded iron formations. In: 72nd Annual international meeting of Society of Exploration Geophysics, pp 13-16

Deng Y, Shi X, Wu J (2016) Application of hydrogeophysics in characterization of subsurface architecture and contamination plumes. J Groundw Sci Eng 4(4):354-366

Dobrin MB, Savit CH (1988) Introduction to geophysical prospecting. McGraw-Hill Book Co, Singapore

Eniola PJ (2019) Assessment of the relevance of the magnetic method in groundwater investigation in a basement complex terrain. Thesis, Obafemi Awolowo University, Ile-Ife, Nigeria

Geological Survey of Nigeria (1965) Geological map of Iwo and its environs. Geological Survey of Nigeria Map, Abuja

Hogg S (2004) GT-gradient tensor gridding, geologic structure example. http://www.shapegeophysics.com/. Accessed 10 Aug 2004

Hood P (1965) Gradient measurements in aeromagnetic surveying. Geophysics 30:891-902

Hsu SK (2002) Imaging magnetic sources using Euler's equation. Geophys Prospect 50:15-25

Iloeje NP (1981) A new geography of Nigeria (new revised edition). Longman Nigeria Ltd., Lagos

Kinnear JA, Binley A, Duque C, Engesgaard PK (2013) Using geophysics to map area of potential groundwater discharge into Ringkoburg Fjord, Demark. Lead Edge Spec Edit Hydrogeophys 2(7):792-796

Kumar D, Ahmed S, Krishnamurthy NS, Dewandel B (2007) Reducing ambiguities in vertical electrical sounding interpretation. $\mathrm{J}$ Appl Geophys 62:16-31

Macdonald A, Calowb RC (2008) Developing groundwater for secure rural water supplies in Africa. Desalination 248:546-556

Muszala SP, Grindlay NR, Bird RT (1999) Three-dimensional Euler deconvolution and tectonic interpretation of marine magnetic anomaly data in the Puerto Rico trench. J Geophys Res 104:29175-29188

Ndougsa-Mbarga T, Feumoe ANS, Manguelle-Dicoum E, Fairhead JD (2012) Aeromagnetic data interpretation to locate buried faults in South-East Cameroon. Geophysica 48(1-2):49-63

Nelson JB (1988) Calculation of the magnetic gradient tensor from total field gradient measurements and its application to geophysical interpretation. Geophysics 53:957-966 
Ogilvy AA (1970) Geophysical prospecting for groundwater in the Soviet Union. In: Morely EW (ed) Geological survey of Canada Economic Geological Report. Mining and Groundwater Geophysics 26, pp 536-543

Olorunfemi MO, Fasuyi SA (1993) Aquifer types and the geoelectric/ hydrogeologic characteristics of part of the central basement terrain of Nigeria (Niger State). J Afr Earth Sci 6(3):309-317

Olorunfemi MO, Oni AG (2019) Integrated geophysical methods and techniques for siting productive boreholes in basement complex terrain of southwestern Nigeria. Ife J Sci 20(1):13-26. https:// doi.org/10.4314/ijs.v21i1.2

Olorunfemi MO, Olanrewaju VO, Avci M (1986) Geophysical investigation of a fault zone-case history from Ile-Ife, Southwest, Nigeria. Geophys Prospect 34:1277-1284

Oni AG (2014) Geophysical field mapping: an integrated geophysical investigation for groundwater potential assessment of Modomo Community in Ile-Ife, Osun State, Southwestern Nigeria. Dissertation, Obafemi Awolowo University, Ile-Ife, Nigeria

Orakwe LO, Olorunfemi MO, Ofoezie IE, Oni AG (2018) Integrated geotechnical and hydrogeophysical investigation of the Epe Wetland Dumpsite in Lagos State, Nigeria. Ife J Sci 20(3):461473. https://doi.org/10.4314/ijs.v20i3.1

Paillet F (2013) Cross-borehole flow profiling-delineating subsurface flow paths within a geophysically defined aquifer framework. Lead Edge Spec Edit Hydrogeophys 32(7):758-785

Phillips JD (2000) Locating magnetic contacts: a comparison of the horizontal gradient, analytical signal and local wavenumber methods. In: 70th Annual international meeting, SEG, expanded abstracts, pp 402-405

Phillips JD (2002) Two-step processing for 3D magnetic source locations and structural indices using extended Euler or analytical signal methods. In: 72nd Annual international meeting, SEG, expanded abstracts, pp 727-730

Reid AB, Allosp JM, Granser A, Millet AJ, Somerton IW (1990) Magnetic interpretation in three dimensions using Euler deconvolution. Geophysics 55:80-91
Robinson J, Slate L, Johnson T, Binley A (2013) Strategies for characterizing fractured rock using cross-borehole electrical tomography. Lead Edge Spec Edit Hydrogeophys 32(7):784-790

Roy PS, Whitehouse J, Cowell PJ, Oakes G (2000) Mineral sand occurrences in the Murray Basins, Southeastern Australia. Econ Geol 95:1107-1128

Ruggeri P, Irving J, Holliger K, Gloaguen E, Lefebvre R (2013) Hydrogeophysical data integration at larger scale: application of Beyesain sequential simulation for the characterization of heterogeneous alluvial aquifer. Lead Edge Spec Edit Hydrogeophys 32(7):766-774

Talwani M (1965) Computation with the help of magnetic anomalies caused by arbitrary. Geophysics 30:797-817

Talwani M, Heirtzler JR (1964) Computation of magnetic anomalies caused by two-dimensional bodies of arbitrary shape. In: Parks GA (ed) Computers in the mineral industries, part 1, vol 9. Stanford University Publication Geological Sciences, Stanford, pp 464-480

Thompson DT (1973) Identification of magnetic source types using equivalent simple models. Paper presentation at the 1973 Fall Annual AGU meeting in San Francisco

Urban TM, Anderson DD, Anderson WW (2012) Multimethod geophysical investigation at an Inupiaq Village Site in Kobuk Vally, Alaska. Lead Edge Spec Sect Archaeol 31:950-956

Vacquier V, Steenland NC, Roland G, Zietz I (1951) Interpretation of aeromagnetic maps. Geol Soc Am Mem 47:289

Wen IJ, Bevis M (1987) Computing the gravitational and magnetic anomalies due to a polygon: algorithms and Fortran subroutines. Geophysics 52:232-238

Zohdy AAR (1969) The use of Schlumberger and Equatorial Soundings in groundwater investigations near El Paso, Texas. Geophysics 34:713-728

Publisher's Note Springer Nature remains neutral with regard to jurisdictional claims in published maps and institutional affiliations. 